\title{
MONIAINEKSINEN KATSAUS 2000-LUVUN YMPÄRISTÖPEDAGOGIIKKAAN
}

CANTELL, HANNELE (toim.) Ympäristökasvatuksen käsikirja. Opetus 2000. PS-kustannus 2004. 241 sivua.

$\mathrm{V}$ ielä 1990-luvulla ympäristökasvatuksellisen sisällyttäminen valtakunnallisen opetussuunnitelman kasvatuspäämääriin oli lähinnä muodollinen teko, jonka ulkoiset paineet, mm. julkinen keskustelu asettivat koulukasvatukselle. Ympäristökasvatuksen periaatteet eivät juuri saaneet aikaan merkittäviä muutoksia koulujen arki- ja opetuskäytännöissä. 2000-luvulla tilanne on muuttunut. Koulujen ja oppilaitosten valtakunnallisen ympäristösertifioinnin kriteerit on julkaistu. Ympäristökatselmuksia ja -ohjelmia suunnitellaan kiivaasti oppilaitoksissa. Kestävän kehityksen periaatteet ovat vakiintuneet koulutuspoliittisiksi toimenpidevaatimuksiksi, joiden noudattaminen edellyttää oppilaitoskohtaisten ympäristöohjelmien rakentamista.

Ympäristökasvatuksen kasvatustieteellisessä tutkimuksessa tilanteeseen on reagoitu kehittämällä erityistä kestävän kehityksen didaktiikkaa ja -pedagogiikkaa. Ympäristökasvatuksen käsikirja on tarkoitettu selkeästi palvelemaan opettajien, koulu- ja nuorisotyön viranomaisten sekä myös opettajiksi opiskelevien akuuttia koulutustarvetta ympäristöasioissa ja erityisesti kestävän kehityksen käsitteen omaksumisessa. Toiseksi teoksen kirjoittajien laajan ammattikirjon perusteella voi päätellä, että kirjan toimittamisella on pyritty yhdistämään ympäristökasvatuksen parissa toimivien valtion viranomaisten, yliopistotutkijoiden ja käytännön ympäristökasvattajien tieto-taitoa samojen kansien väliin. Yhteistyö ympäristökasvatuksen eri asiantuntijoiden sekä teorian ja käytännön välillä on tullutkin yhä tärkeämmäksi ympäristökysymyksen institutionalisoitumisen myötä.

Teoksen artikkelit on jaettu teemoittain kahdeksaan päälukuun. Päälukujen lopussa on pohdintatehtäviä ja kysymyksiä, joita voi hyödyntää omatoimisessa tai ohjatussa opiskelussa. Niiden tarkoitus on myös herättää lukijaa jäsentämään ja pohtimaan luvun keskeisiä teemoja. Osa tehtävistä lisää pohdinnan mahdollisuuksia, osa välttämättä ei. Pohdintatehtävien joukosta löytyy keinotekoisia kysymyksiä, jotka pakottavat vastaamaan etukäteen artikkelin sisältämien näkökulmien ja teemojen mukaisesti, eivätkä herätä juurikaan mahdollisuuksia kriittiseen pohdintaan. Lukijaystävällisyyttä ja teoksen hyödynnettävyyttä on lisätty kokoamalla teoksen loppuun eri yhteistyötahojen nimet, osoitteet ja www-sivut. Artikkeleissa usein käytetyt internetsivujen viittaukset olisi myös ollut hyvä koota teoksen loppuun.

Artikkelien näkökulmat ovat moninaiset. Ympäristökasvatusta tarkastellaan mm. ympäristöpsykologisesta, ympäristönsuojelutieteellisestä, didaktisesta, ympäristöfilosofisesta ja koulutussosiologisesta näkökulmasta. Tämä on erityisen hyvä asia, koska monitieteisyys on nykyisin haaste kaikille tie- teenaloille, jotka käsittelevät ympäristökysymyksiä. Monitieteisyys on myös asetettu ympäristökasvatuksen tutkimuksen keskeiseksi päämääräksi (http://www.1weec.net/ general_conclusions.pdf). Näkökulmien moninaisuus palvelee myös kouluja ja oppilaitoksia niiden integroidessa ympäristöasiat osaksi koulun toimintakulttuuria - ei siis ainoastaan osaksi eri aineiden opetusta. Teos tarjoaakin päivitettyä teoriaa ympäristökasvatuksen suunnittelun ja arvioinnin pohjaksi ja antaa käytännön opastusta ympäristökasvatuksen toteutukseen opetuksessa ja kasvatus- ja koulutusorganisaatioiden koko toimintaympäristössä.

Artikkelien välistä yhtenäisyyttä on lisätty jäsentämällä teoksen eri lukujen sisällöt Palmerin esittämän ympäristökasvatuksen ns. puumallin mukaan. Ratkaisu lisää teosten yhteneväisyyttä, mutta voi epäillä, että se on saattanut rajata teoksen sisällön valintaan sisältyviä ratkaisuja etukäteen. Kuten LiliAnn Wolff toteaa, kaikkien mallien ongelmana on, että ne organisoivat ympäristökasvatuksen sisältöä jonkin tietyn hierarkkisen järjestyksen mukaan. Kaikki tähän järjestykseen sopimattomat näkökulmat rajautuvat luonnollisesti mallin ulkopuolelle.

Kaikkien ympäristökasvatuksen olemukseen ja sen tehtävään liittyvien mielipiteiden ja näkökantojen annetaan kukkia vapaasti luvussa "Puheenvuoroja”. Erityisesti Wolffin artikkeli "Tulevaisuuteen tähtäävä 
kasvatus" haastaa virallisen ympäristökasvatuksen tutkimuksen periaatteet ja käytännön didaktiset mallit. Wolffin artikkelissa tulevaisuuskasvatus ymmärretään todellisuuteen kasvattamisena ja ympäristökasvatus ongelmapainotteisena, freirelaisena sorrettujen pedagogiikkana. Aidosti kriittiset näkökulmat eivät ole vielä saaneet - mielestäni - riittävää huomiota ns. virallisen ympäristökasvatuksen tutkimuksessa ja käytännöissä. Miksi kriittiset näkökulmat on esitetty ikään kuin erillisinä, omassa luvussaan (-luokassaan)? Kriittinen momentti olisi voitu ylettää läpikulkevaksi teemaksi.

\section{MÄÄRITTELYN ONGELMA}

Teoksen toimittaja Hannele Cantell toteaa, että teos ei ole pelkkä menetelmäopas. Se, mikä käsittääkseni erottaa sen menetelmäoppaasta, on sen pyrkimys hahmottaa ympäristökasvatuksen opetus-oppimisprosessin ja sen arvioinnin taustalla vaikuttavia yleisiä käsityksiä ympäristöstä, luonnosta, kestävästä kehityksestä ja itse ympäristökasvatuksesta. Tulkintani mukaan teoksen tekijöiden (toimittajan) haasteellinen pyrkimys on esittää yhtenäinen, mutta samalla moniaineksinen teoria ympäristökasvatuksesta, tai nykytermein ilmaistuna kestävän kehityksen pedagogiikasta. Tämä pyrkimys lienee ollut perusteena sille, että kirjan rakenne ja sisältö jäsentyvät yhden teorian, sateenkaarimallina toimivan Palmerin ympäristökasvatuksen puumallin perustalle. Pyrkimys yhtenäisen, mutta samalla moniaineksisen teorian rakentamiseen ilmenee myös siinä, että teoksessa pyritään määrittelemään johdonmukaisesti käsit- teet ympäristö, ympäristökasvatus ja kestävä kehitys yhdistämällä hyvin erilaisia näkökulmia tietyn teeman alle. Asioiden moniaineksista merkityksellisyyttä on kuitenkin vaikea vangita täsmällisesti määritellyiksi käsitteiksi. Tätä ongelmaa ei myöskään tässä teoksessa voida ohittaa.

Se, että esitetään asioiden erilaisia määritelmiä, ei ole luonnollisestikaan huono asia. Päinvastoin. Mutta silloin, kun näin tehdään, olisi määritelmien taustalla vaikuttavia merkityksiä myös pohdittava tietoisesti. Olisi pohdittava sitä, miten eri merkitykset ovat syntyneet, miksi jollekin asialle tai asiantilalle annetaan tietty merkitys (intressien vaikutus) ja miten eri merkitykset ovat toisiinsa suhteessa eli olisi pohdittava asioiden suhdetta niiden merkitsijään, kuten yhteiskuntaan.

Teos sisältää tämäntyyppistä pohdintaa erityisesti pääluvussa 2 ja 3. Niistä toisessa LiliAnn Wolff tarkastelee kestävän kehityksen kasvatuksen ja ympäristökasvatuksen suhdetta. Hän toteaa, että kestävän kehityksen kasvatus asettaa aivan uudenlaiset odotukset koulujen ja koko yhteiskunnan toiminnalle. Kysymys on emansipaatiosta ja pyrkimyksestä kyseenalaistaa koko länsimainen kulttuuri ja elämäntapa. Risto Willamo pohtii luonnolle annettuja merkityksiä ja erilaisia näkemyksiä ihmisen luontosuhteesta. Hän toteaa, että luontosuhteemme on kaventunut ja pirstoutunut. Ihmiset eivät tiedosta omaa "henkilökohtaista ekologiaansa”. Siksi ympäristökasvatuksessa tulisi pohtia ja tutkia sitä, miten oma olemisemme on riippuvainen luonnon prosesseista. Alaluvussa Liisa Suomela ja
Sirpa Tani esittelevät kolme erilaista ympäristön määritelmää, jotka nousevat eri tieteenalojen perustalta, luonnontieteestä, ympäristöetiikasta ja -filosofiasta, ympäristöpsykologiasta sekä yhteiskuntatieteestä. Luku on teoksen mielenkiintoisimpia, mutta lukijalle myös haasteellisimpia. Voi epäillä, että luvun moninaisuus saattaa hämmentää sellaista lukijaa, jolla on vähän tietoa ympäristökysymyksen erilaisista tieteellisistä ja yhteiskunnallisista tulkinnoista ja siitä, mitä johtopäätöksiä näistä tulkinnoista on tehtävissä ympäristökasvatuksen tehtäviin ja merkityksiin yhteiskunnassa.

\section{YHTEISKUNNALLINEN SIVISTYS JA VASTUULLINEN VAPAUS?}

Luvussa 4 palataan jälleen "maan pinnalle" ja irrottaudutaan kestävän kehityksen, luonnon ja ympäristön monimerkityksellisyyden kaaosmaisuudesta. Lukujen välille muodostuu ikään kuin katkos: siitä huolimatta, että kestävän kehityksen, luonnon ja ympäristön todetaan ilmenevän meille moninaisena ja ristiriitaisena, oletetaan, että ympäristökasvatuksen sisältöjä ja tavoitteita kyetään mallintamaan ja arvioimaan erityyppisten universaalisten tavoitteiden hierarkkisen järjestyksen mukaisesti. Yhdyn LiliAnn Wolffin toteamukseen tämän teoksen puheenvuorossa: "Usein vastauksia etsitään siihen, mitä ihmisen pitää tietää, tehdä ja osata. Viisaampaa on miettiä, miten ihmiset oppivat ja mitä he haluavat osata ja oppia.”

Luvussa 4 esitetään neljä ympäristökasvatuksen teoreettista mallia: Hungerfordin ja Vol- 
kin (1990) ympäristövastuullista käyttäytymistä tarkasteleva malli, Jerosen ja Kaikkosen (2001) ikätasoja painottava malli, Koskisen (1999) osallistuvan ympäristökasvatuksen malli sekä Palmerin (1998) ns. ympäristökasvatuksen puumalli. Teoksen tekijät korostavat, että mallit eivät sinällään ole tärkeitä, vaan ne ovat hyödyllisiä työkaluja, jotka auttavat ympäristökasvatuksen käytännön suunnittelua, toteuttamista ja arviointia. Itse koen, että erilaisten teoreettisten mallien tuntemus on nimenomaan tärkeää siinä mielessä, että valitut teoriat tarkastelevat ympäristökysymystä ja -kasvatusta tietystä rajatusta ja rajallisesta näkökulmasta. Kasvattajan tulee tiedostaa oman käyttöteoriansa sisältämät rajoitukset, ennakkooletukset ja niiden kulttuurinen sidonnaisuus.

Ympäristökasvatuksen tutkimuksessa yleisesti hyväksyttyjen teoreettisten mallien - jotka useimmat perustuvat Hungerfordin ja Volkin ympäristövastuullista toimintaa ja siihen vaikuttavia tekijöitä koskevaan teoriaan - perusongelma näyttäisi olevan kaksi toisiinsa sidoksissa olevaa ilmiötä: ympäristöongelmien tieteellistäminen ja yksilöllistäminen. Ympäristökasvatuksessa ympäristöongelmia käsitellään eri tieteenalojen näkökulmasta, mutta samalla ympäristökysymykset mielletään kokemuksellisiksi ja psykologisiksi ilmiöiksi, jokaiselle henkilökohtaiseksi tiedolliseksi ja emotionaaliseksi skeemaksi. Asenne- ja arvokasvatuksen pyrkimyksenä on tukea tämän skeeman rakentumista. Toiseksi, ympäristökasvatuksessa ja sen tutkimuksessa on tyypillistä ymmärtää ympäristöongel- mat ja -konfliktit globaaleina ympäristönsuojelupoliittisina ja hallinnollisina kysymyksinä, joihin oppilaat tulee sosiaalistaa. Kestävän kehityksen periaatteiden uskotaan rakentuvan demokraattisen poliittisen päätöksenteon ja tasa-arvoisen yhteiskuntajärjestyksen perustalle. Kun ympäristökasvatuksessa käsitellään ympäristöeettisiä tai -poliittisia kysymyksiä, on tyypillistä, että ympäristöasioista tehdään samanaikaisesti henkilökohtaisia (kansalaistietojen ja taitojen hallinta).

Ympäristökasvatuksessa on siis tyypillistä se, että ympäristöongelmia normalisoidaan. Ympäristöongelmien normalisoinnilla viitataan laajempaan yhteiskunnalliseen ilmiöön, ns. läpiekologisoitumiseen, missä ekologinen käsitteistö ja retoriikka leviävä yhteiskunnan kaikkiin osa-alueisiin taloudesta ja politiikasta kasvatukseen. Ympäristökasvatuksen käsikirja on konkreettinen dokumentaatio tästä ilmiöstä. Olisi ollut toivottavaa ja odotettavaa, että teos olisi sisältänyt enemmän elämänkatsomuksellisia näkökulmia ympäristökysymykseen, koska ympäristöongelmista on tullut yhä enemmän poliittinen määrittelykysymys. Kenellä on valta määritellä länsimaisen yhteiskunnan muutoksen suunta?

\section{YMPÄRISTÖKASVATUKSEN PARADOKSI}

Tästä teoksesta - kuten useista muistakin ympäristökasvatuksen oppikirjoista ja tutkimuksista - heijastuu vahva usko kestävään kehitykseen yhteiskunnallisena projektina. Tärkeäksi asiaksi koetaan se, että kestävän kehityksen periaatteesta kyetään muodostamaan johdonmukainen ja loogi- nen viitekehys ympäristökasvatuksen toteuttamiselle. Ympäristökasvatuksessa ja sen tutkimuksessa ei juurikaan pohdita kestävän kehityksen eettisiin periaatteisiin sisältyviä ongelmia, kuten sitä, miten kestävä kehityksen ideologiassa kyetään yhdistämään inhimillisen vapauden ja tasa-arvon vaatimukset niihin velvoitteisiin, joita yhteiskunnalla on luontoa kohtaan. Keskeiseksi ongelmaksi kestävässä kehityksessä muodostuu sen utooppinen tulevaisuuden ja yhteiskunnan ideaali.

Ympäristökasvatuksen tulisi olla lähinnä etsimisliike, joka tarjoaa uusille sukupolville välineitä inhimilliseen kasvuun ja yhteisölliseen vastuuseen. Vastuu edellyttää vapautta. Ympäristökasvatuksen tulisi sitoutua todellisuuteen ja osoittaa se, $m i$ ten tämän päivän yhteiskunta on rakennettu ja miten ihminen itse pystyy vaikuttamaan asioiden kulkuun. Elämänkatsomuksen sisäistäminen edellyttää kykyä tehdä eroja eri valintojen ja niiden seurausten välille. Toiseksi se on kykyä hahmottaa yhteyksiä näennäisesti erillisten asioiden välille.

Rajallisista näkökulmistaan huolimatta, Ympäristökasvatuksen käsikirja on mainio ympäristökasvatuksen teorian ja käytännön päivitys. Erityisesti teoksessa esitetyt konkreettiset ympäristökasvatuksen projektit ja toimintamallit (luvut 6 ja 7) on kuvattu mukaansatempaavasti ja ne havainnollistavat ympäristökasvatuksen toteuttamistapoja kouluissa, nuorisotyössä, työyhteisöissä, perheissä ja organisaatiossa.

\section{Eila Louhimaa}

Kirjoittaja väitteli vuonna 2002 ympäristökasvatuksesta. 